\title{
Molecular alterations of isocitrate dehydrogenase 1 and 2 (IDH1 and IDH2) metabolic genes and additional genetic mutations in newly diagnosed acute myeloid leukemia patients
}

\author{
Sadudee Chotirat ${ }^{1}$, Wanna Thongnoppakhun ${ }^{2}$, Orathai Promsuwicha ${ }^{3}$, Chetsada Boonthimat ${ }^{3}$ and
} Chirayu U Auewarakul ${ }^{3,4^{*}}$

\begin{abstract}
Background: Isocitrate dehydrogenase 1 and 2 (IDH1 and IDH2) metabolic genes encode cytosolic and mitochondrial enzymes that catalyze the conversion of isocitrate to $\alpha$-ketoglutarate. Acquired somatic mutations of IDH1 and IDH2 have recently been reported in some types of brain tumors and a small proportion of acute myeloid leukemia (AML) cases.

Methods: Two-hundred and thirty newly diagnosed AML patients were analyzed for the presence of IDH1 and IDH2 heterozygous mutations by polymerase chain reaction-denaturing high performance liquid chromatography (PCR-DHPLC) followed by direct sequencing. Clinical and biological characteristics were analyzed and correlated to the IDH mutational status. Coexisting mutations such as FLT3, PML-RARA, RAS, AML1, and NPM1 mutations were additionally explored.
\end{abstract}

Results: The prevalence of IDH1 and IDH2 mutations was $8.7 \%$ (20/230) and 10.4\% (24/230), respectively. Six missense mutations were identified among IDH1-mutated cases; p.R132H $(n=8)$, p.R132C $(n=6)$, p.R132S $(n=2)$, p.R132G ( $n=2)$, p.R132L $(n=1)$, and p.I99M $(n=1)$. Two missense mutations were found in IDH2-mutated cases; p.R140Q $(n=20)$ and p.R172K $(n=4)$. No patients had dual IDH1 and IDH2 mutations. About 18\% of AML with normal cytogenetics and $31 \%$ of acute promyelocytic leukemia had IDH mutations. Half of the IDH-mutated cohort had normal karyotype and the major FAB subtype was AML-M2. Interestingly, IDH1- and IDH2-mutated cases predominantly had NPM1 mutations (60-74\%) as compared to the wild type $(\mathrm{P}<0.001)$. Very few IDH-mutated cases had FLT3 and/or RAS abnormalities and none of them had AML1 mutations. Older age and higher median platelet counts were significantly associated with IDH2 mutations although the clinical impact of either IDH1 or IDH2 mutations on patients' overall survival could not be observed.

Conclusion: Overall, 19\% of newly diagnosed AML patients had alterations of IDH genes. No patients concurrently carried both $I D H 1$ and $I D H 2$ mutations suggesting that these mutations were mutually exclusive. NPM1 mutation appears as a major coexisting genetic mutation in IDH-mutated patients. Our present data failed to support the prognostic relevance of IDH mutations although alterations of these metabolic genes potentially have an important role in leukemia development.

Keywords: Acute myeloid leukemia, Isocitrate dehydrogenase, Metabolic enzymes, IDH1, IDH2, Cooperative mutations, Normal karyotype

\footnotetext{
* Correspondence: chirayuaue@yahoo.com

${ }^{3}$ Department of Medicine, Faculty of Medicine Siriraj Hospital, Mahidol

University, Bangkok, Thailand

Full list of author information is available at the end of the article
} 


\section{Background}

Acute myeloid leukemia (AML) is a malignant hematologic disorder characterized by abnormal expansion of differentiation-defective myeloid cells [1]. Various chromosomal aberrations have been identified in AML patients and are uniquely associated with distinct clinical entities and prognostic relevance [2]. Although 40$50 \%$ of AML cases do not carry any detectable chromosomal abnormalities, a fraction of them are found to have mutations of genes that normally function in cell proliferation, differentiation, and survival such as FLT3, NPM1, RAS, WT1, and AML1 [3,4]. Moreover, through a rapid whole genome sequencing approach, it is now evident that at least half of the AML cases with normal karyotype have readily identifiable genomic abnormalities [5].

Alteration of cellular metabolism has recently been proposed as a novel oncogenetic mechanism [6,7]. Isocitrate dehydrogenase (IDH) is one the enzymes that, if defective, lead to abnormal cellular metabolism $[8,9]$. There are three IDH isoforms; IDH1 is in the cytoplasm whereas IDH2 and IDH3 are localized in the mitochondria [9,10]. IDH1 and $I D H 2$ genes encode enzymes that catalyze oxidative decarboxylation of isocitrate into $\alpha$ ketoglutarate $(\alpha-K G)$ by utilizing nicotinamide adenine dinucleotide (NAD) or NAD phosphate (NADP) as a cofactor to generate NADH or NADPH, respectively [11]. In 2008, a novel mutation of $I D H 1$ gene was firstly described in patients with glioblastoma multiforme (GBM). Subsequent studies additionally identified such mutations in $>70 \%$ of young adults with low-grade glioma and $80 \%$ of patients with secondary GBM [12-14]. Meanwhile in 2009, IDH1 mutation was reported in a subset of AML patients lacking specific chromosomal aberrations [5] and in 2010, IDH2 mutation was identified in AML, myelodysplastic syndrome (MDS), and myeloproliferative neoplasms (MPN) [15-17]. The worldwide frequencies of $I D H 1$ and $I D H 2$ mutations in newly diagnosed AML patients range from $2 \%$ to $14 \%$ and $1 \%$ to $19 \%$, respectively, with the mutations mostly restricted to codon R132 of IDH1 and codon R140 of IDH2 [5,15,18-32]. Biochemical and molecular analyses reveal that mutations at the evolutionarily conserved site of $I D H$ lead to interruption of the normal ability of enzyme to bind substrates and subsequent acquisition of novel enzymatic activity resulting in a substantial increase of oncometabolite $R(-)$-2-hydroxyglutarate (2HG) through $\alpha-K G$ conversion $[8,19,20]$. The accumulation of elevated $2 \mathrm{HG}$ induces global DNA hypermethylation and interruption of hematopoietic differentiation [33,34].

In the present study, we aimed to characterize $I D H 1$ and $I D H 2$ mutations in newly diagnosed AML patients and investigate their correlations to other parameters such as clinical and hematologic characteristics, cytogenetics and additional genetic mutations.

\section{Methods \\ Leukemia samples}

Leukemic samples from 230 newly diagnosed AML cases were consecutively recruited into the study. Clinical and biological characteristics were collected including clinical history, complete blood counts, peripheral blood (PB) smear, bone marrow (BM) studies, flow cytometric immunophenotyping, and chromosome analysis. Mononuclear cells (MNC) were isolated from the leukemic samples by Ficoll-Hypaque density-gradient centrifugation and subsequently used for molecular analysis. Twenty consented normal individuals were used as controls. Patients were treated according to the standard AML regimen which included idarubicin and cytarabine induction therapy followed by high-dose cytarabinebased consolidation phase. This study was approved by the Ethical Committee for Human Research, Faculty of Medicine Siriraj Hospital, Mahidol University.

\section{Mutational analysis of $I D H 1$ and $I D H 2$}

Genomic DNA was extracted using standard phenolchloroform method or Gentra Puregene Blood Kit (Qiagen, Hidden, Germany) according to the manufacturer's protocol. DNA amplicons harbouring exon 4 of $I D H 1$ and $I D H 2$ were amplified by polymerase chain reaction (PCR) using the primer pair; IDHIf (5'-AGCTC TATATGCCATCACTGC-3'), IDH1r (5'-AACATGCAAAATCACATTATTGCC-3'), IDH2f(5' - AATTTTA GGACCCCCGTCTG-3'), and IDH2r (5'-CTGCAGAGACAAGAGGATGG-3') [13]. PCR reactions were performed in a total volume of $20 \mu \mathrm{L}$ containing $50 \mathrm{ng}$ of genomic DNA, PCR master mixture consisting of $1 \mathrm{x}$ Phusion ${ }^{\circledR}$ HF Buffer (F-520), $200 \mu \mathrm{M}$ dNTPs, $0.5 \mu \mathrm{M}$ of each primer, $0.02 \mathrm{U} / \mu \mathrm{L}$ Phusion ${ }^{\circledR}$ DNA polymerase, and Milli-Q water. The PCR was carried out in a Perkins Elmer PCR2400 thermal cycler (Applied Biosystems, Foster City, CA) using the following steps: initial denaturation at $98^{\circ} \mathrm{C}$ for 30 seconds (sec), 35 cycles at $98^{\circ} \mathrm{C}$ for $10 \mathrm{sec}, 60^{\circ} \mathrm{C}$ for $30 \mathrm{sec}$. and $72^{\circ} \mathrm{C}$ for $30 \mathrm{sec}$, and final extension at $72^{\circ} \mathrm{C}$ for 5 minutes (min). Both amplicons were screened for heterozygous mutations by denaturing high-performance liquid chromatography (DHPLC) on a WAVE 3500 HT with DNASep ${ }^{\circledR}$ HT cartridge technology (Transgenomic Inc, Omaha, NE, USA). The optimized condition and temperature were predicted by the Navigator ${ }^{\mathrm{TM}}$ software to determine chromatographic peak pattern. PCR crude sample was injected into DHPLC column and the optimal temperature for IDH1 was $58.5^{\circ} \mathrm{C}$ and IDH2 was $64^{\circ} \mathrm{C}$. Each 
DHPLC chromatogram was compared to a wild-type reference. The sensitivity of our assay was determined by performing a dilution series containing a different percentage (\%) of mutant and wild-type IDH concentrations. Abnormal DHPLC peaks could be clearly detected in $50 \%, 20 \%, 10 \%, 5 \%$, and $3.33 \%$ dilutions. The mutational chromatograms were re-amplified in an independent PCR reaction and further subjected to direct sequencing. The sequences were compared to the wildtype IDH1 and IDH2 cDNA (GenBank Accession number, NM_005896.2 and NM_002168.2, respectively) [25].

\section{Analysis of additional molecular aberrations}

Mutational analyses of FLT3, PML-RARA, RAS, AML1, and NPM1 were performed according to our previously described method [35-39]. Briefly, the DNA or RNA was extracted, then the genes of interest were amplified and detected by gel electrophoresis (FLT3), denaturing high performance liquid chromatography (DHPLC) (NPM1), single-strand conformational polymorphism (SSCP) (RAS and AML1). For PML-RARA, the cDNA was synthesized and reverse transcriptase-polymerase chain reaction (RT-PCR) performed.

\section{Statistical analysis}

The relationship between $I D H$ mutations and various patient characteristics such as age, Hb count, WBC count, platelet count, and percentages of blasts was determined by the student $t$-test, equal variances not assumed for continuous variables. Categorical variables such as FAB classification, cytogenetics, and test. The KaplanMeier method and the log-rank test were utilized to estimate the distribution of OS [40]. For all analyses, a p-value of less than 0.05 was considered statistically significant. All reported p-values were 2-sided.

\section{Results}

\section{Frequency and type of IDH 1 and IDH2 mutations}

In a total cohort of 230 consecutive AML patients (36 acute promyelocytic leukemia (APL) and 194 non-APL), 44 patients with $I D H$ mutation were identified (19.13\%) by DHPLC showing abnormal chromatogram patterns that were different from the wild-type profiles. These mutations were further confirmed by sequencing analysis (Figure 1). Twenty IDH1 mutations (8.7\%) included six missense mutations leading to amino acid (AA) substitution with different frequencies: c.G395A; p.R132H in 8 cases $(40.0 \%)$, c.C394T; p.R132C in 6 cases $(30.0 \%)$, c. C394A; p.R132S in 2 cases (10.0\%), c.C394G; p.R132G in 2 cases (10.0\%), c.G395T; p.R132L in 1 cases (5.0\%), and c.A297G; p.I99M in 1 cases (5.0\%) (Table 1). In addition, one silent polymorphism (c.315 G > T; IDH1 ${ }^{G 105 G}$ ) was observed in 3 patients (1.30\%). Twenty-four IDH2 mutations (10.4\%) included two missense mutations with

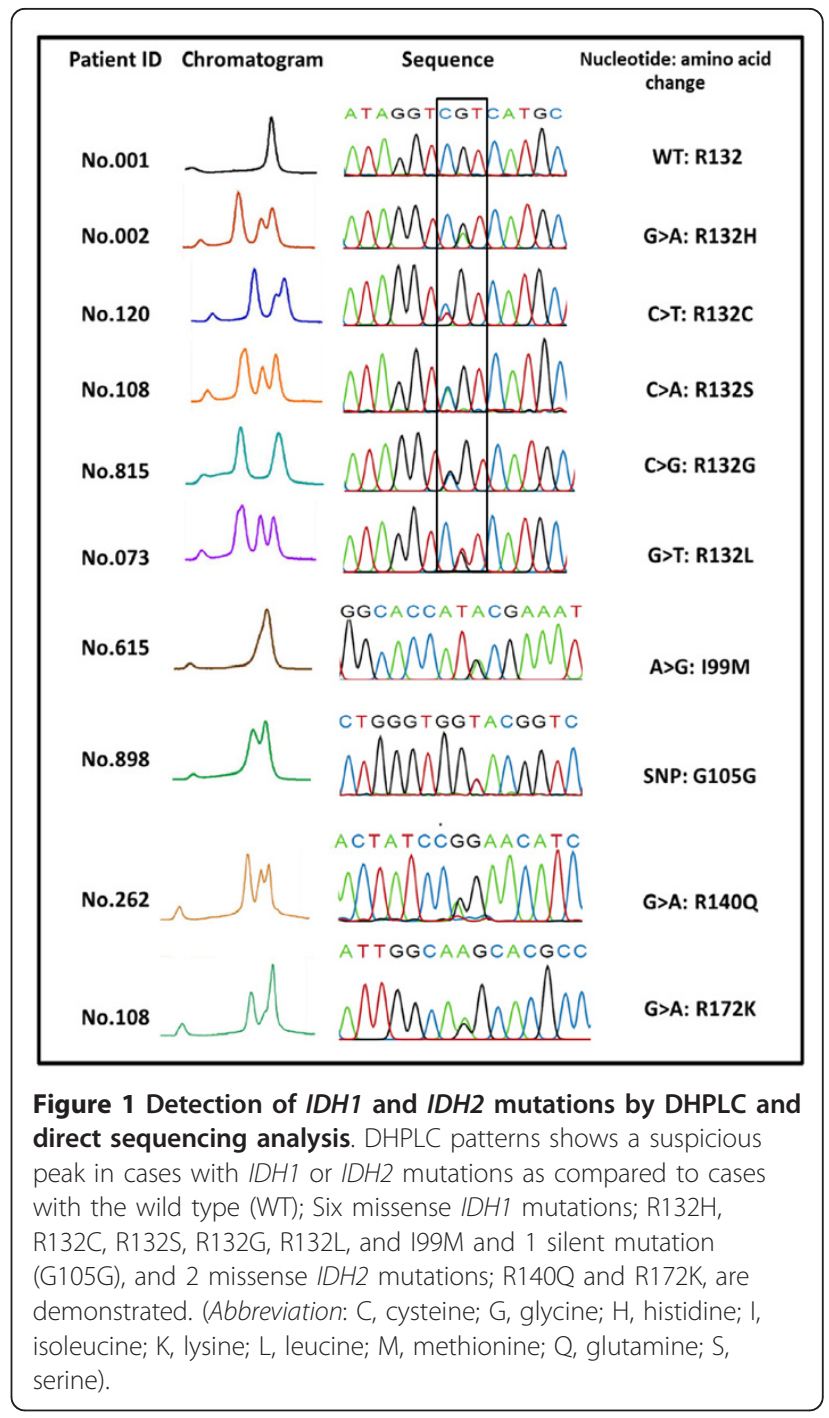

different frequencies: c.G419A; p.R140Q in 20 cases $(83.3 \%)$ and c.G515A; p.R172K in 4 cases (16.7\%). All patients with the mutations were heterozygous and retained a wild-type allele (Figure 1). No mutated patients harbored dual mutations of both genes, indicating that these mutations are mutually exclusive.

\section{Clinical parameters and morphologic subtypes of patients with $I D H 1$ or IDH2 mutations}

Twenty IDH1-mutated patients showed no significant differences in age, hemoglobin level, WBC counts, platelet counts or percentages of blasts as compared to the IDH1 wild-type group, although a trend towards more females was observed ( 15 females vs 5 males; $P=.058$ ). Twentyfour IDH2-mutated patients also showed no significant differences in sex, WBC counts or percentages of blasts but an older age (49.5-year vs. 43-year; $P=.001$ ), a higher platelet count (59 vs. $45 \times 10^{9} / \mathrm{L} ; P=.048$ ), and a trend 
Table 1 Type of IDH1 and IDH2 mutations identified in 230 AML patients

\begin{tabular}{cccc}
\hline Mutation & $\begin{array}{c}\text { Nucleotide } \\
\text { change }\end{array}$ & $\begin{array}{c}\text { Predicted protein } \\
\text { change }\end{array}$ & $\begin{array}{c}\text { No. of } \\
\text { patients }\end{array}$ \\
\hline IDH1* $^{*}$ & & & \\
C.G395A & CGT-CAT & p.R132H & 8 \\
c.C394T & CGT-TGT & p.R132C & 6 \\
c.C394A & CGT-AGT & p.R132S & 2 \\
c.C394G & CGT-GGT & p.R132G & 2 \\
c.G395T & CGT-CTT & p.R132L & 1 \\
c.A297G & ATA-ATG & p.I99M & 1 \\
IDH2** & & & \\
c.G419A & CGG-CAG & p.R140Q & 20 \\
c.G515A & AGG-AAG & p.R172K & 4 \\
\hline
\end{tabular}

Abbreviation: $\mathrm{AML}$, acute myeloid leukemia; $\mathrm{C}$, cysteine; $\mathrm{G}$, glycine; $\mathrm{H}$, histidine $\mathrm{I}$, isoleucine; $\mathrm{K}$, lysine; $\mathrm{L}$, leucine; $\mathrm{M}$, methionine; $\mathrm{Q}$, glutamine; $\mathrm{S}$, serine *IDH1 nucleotide numbering based upon the National Center for Biotechnology Information sequence NM_005896.2

**IDH2 nucleotide numbering based upon the National Center for Biotechnology Information sequence NM_002168.2

towards higher hemoglobin level $(9.25 \mathrm{~g} / \mathrm{dL}$ vs. $7.7 \mathrm{~g} / \mathrm{dL}$; $P=.059)$ were observed in the $I D H 2$-mutated group as compared to the wild-type group (Tables 2 and 3 ). Among IDH1-mutated cases, the majority was classified as AML with maturation (AML M2) (13/20 cases, $65 \%)$ followed by APL (5/20 cases, $25 \%)$. None of the cases with APL, acute monoblastic or monocytic leukemia, acute erythroid leukemia, and acute megakaryoblastic leukemia was found among IDH1-mutated group. Similarly, AML with maturation (AML M2) was the most common subtype among the IDH2-mutated group (11/24 cases, 46\%) (Table 3). The second most common subtypes were APL (6/24 cases, 25\%) and acute myelomonocytic leukemia $(6 / 24$ cases, $25 \%)$. The OS of patients with or without $I D H 1$ or $I D H 2$ mutations did not differ among the entire series of AML patients and AML patients with normal cytogenetics $(P=0.200$ and 0.272 , respectively). No significant difference was demonstrated in subgroups of younger patients (age $<60$ ) and patients with/without additional mutations as compared to the wild-type patients $(P=0.471$ and 0.812 , respectively).

\section{Chromosomal patterns and additional molecular aberrations in patients with $I D H 1$ or $I D H 2$ mutations}

Cytogenetic information was available in 226 of 230 patients, 126 patients (55.75\%) of whom had normal karyotype and 100 patients (44.25\%) had an aberrant karyotype. Of 20 AML cases with IDH1 mutation, 11 cases had normal karyotype (55\%). In the aberrant karyotype, we found 5 cases with $t(15 ; 17)$ chromosome translocation, 2 cases with $\operatorname{del}(9 \mathrm{q})$, and 1 case with trisomy 8 (Table 2). Of 24 cases with IDH2 mutation, 12 cases had normal karyotype (50\%). In the aberrant karyotype, we observed 6 cases with $t(15 ; 17), 2$ cases were
IDH2 R172K harboring trisomy 11, 1 case with trisomy 8,1 case with $\mathrm{t}(8 ; 21)$, and 1 case with $\operatorname{del}(12)$ (p12.1p13.1) (Table 3).

IDH1 mutations were significantly associated with NPM1 mutation as compared with wild-type cases (14/ $19,74 \%$ vs. $45 / 185,24 \% ; P<0.001$ )(Table 4 ). Some cases had additional mutations including FLT3-ITD, FLT3-TKD, NRAS, and PML-RARA. IDH2 mutations were also significantly associated with NPM1 mutations when compared with the respective wild-type cases (12/ $20,60 \%$ vs. $47 / 184,26 \% ; P<0.001$ )(Table 4$). A M L 1$ mutations were not observed in any mutated $I D H 1$ or IDH2 patients.

\section{Discussion}

In the present study, we developed a screening DHPLC method followed by sequencing analysis to detect and confirm the presence of $I D H$ mutations in newly diagnosed AML patients. Twenty cases of IDH1 mutations and 24 cases of $I D H 2$ mutations were discovered among the entire newly diagnosed AML cohort. Previous reports from the Asia continent were available from two countries, i.e. Taiwan [18] and China [28,31,32] while the Western studies were from USA [5,15,20,22,29], Canada [19], France [41], Germany [21,23,25,27], the Netherlands [24], and UK [26,30] (Table 5). The overall frequency of $I D H$ mutations appears to vary between 2$14 \%$ for $I D H 1$ and $1-19 \%$ for $I D H 2$ from most Western reports $[5,15,19,27,29,30,41]$. Worthy of note, the frequency of $I D H 1$ mutations in our population of $8.4 \%$ was comparable to $8.5 \%$ in the first study reported by Mardis et al. in 2009 [5] although these figures were somewhat higher than those of the Chinese AML studies $(5.5 \%, 5.6 \%, 6.3 \%$, and $3.6 \%)[18,28,31,32]$. The frequency of $I D H 2$ mutations of $10.4 \%$ in our cases was also slightly higher than the only available $I D H 2$ study from Asia $(8.3 \%, 4 / 48)$ [28]. The frequency discrepancies among various studies may reflect the variable inclusion criteria of the study samples, the variable sensitivity of the detection assays, the selective inclusion or exclusion of certain $I D H$ aberrations or the true racial differences.

IDH1 mutations consisting of six different amino acid exchanges at p.R132 $(\mathrm{n}=19)$ and p.I99M $(\mathrm{n}=1)$ were identified. Within the p.R132 group, arginine was replaced by histidine $(\mathrm{R} 132 \mathrm{H})$ in most cases $(\mathrm{n}=8$, $40 \%$ ), followed by cysteine ( $132 \mathrm{C} ; \mathrm{n}=6,30 \%$ ), serine (R132S; $\mathrm{n}=2,10 \%)$, glycine (R132G; $\mathrm{n}=2,10 \%$ ) and leucine (R132L, $\mathrm{n}=1,5 \%)$. This pattern was extremely different to the mutation pattern reported in glioma, where $\mathrm{R} 132 \mathrm{H}$ was predominant observed in $88 \%$ of all cases while $\mathrm{R} 132 \mathrm{C}$ present in only $4.5 \%$ [13]. To date, results from structural and functional assays by several multicenter trials suggested that IDH1 R132, which resides at the active site of enzyme substrate affinity, 
Table 2 Characteristics of AML patients with a wild type or mutated IDH1

\begin{tabular}{|c|c|c|c|c|}
\hline Variable & All cases & $I D H 1^{m}$ & $I D H 1^{\mathrm{wt}}$ & $P^{*}$ \\
\hline No. of cases & 230 & 20 & 210 & \\
\hline No. of males/females & $101 / 129$ & $5 / 15$ & $96 / 114$ & .058 \\
\hline Age, years & & & & $.860^{\dagger}$ \\
\hline Median (range) & $44(13-86)$ & $42.5(15-85)$ & $45(13-86)$ & \\
\hline Hemoglobin, $\mathrm{g} / \mathrm{dL}$ & & & & $.311^{\dagger}$ \\
\hline Median (range) & $7.8(1.4-14.5)$ & $7.4(2.9-10.8)$ & $7.85(1.4-14.5)$ & \\
\hline WBC count, $\times 10^{9} / \mathrm{L}$ & & & & $.323^{\dagger}$ \\
\hline Median (range) & $27.7(0.6-494.4)$ & $26.9(1.0-190.9)$ & $27.7(0.6-494.4)$ & \\
\hline Platelet, $\times 10^{9} / \mathrm{L}$ & & & & $.923^{\dagger}$ \\
\hline Median (range) & $46(1.8-965)$ & $56(16.9-386)$ & $45.5(1.8-965)$ & \\
\hline Percentage of blasts & & & & $.738^{+}$ \\
\hline \multirow[t]{2}{*}{ Median (range) } & 70.19 (6.69-95.44) & $75.8(13.3-91.4)$ & $69.77(6.69-95.44)$ & \\
\hline & & Patients (\%) & Patients (\%) & \\
\hline \multicolumn{5}{|l|}{ FAB classification } \\
\hline Mo & 3 & $1(5)$ & $2(0.9)$ & \\
\hline M1 & 51 & $1(5)$ & $50(23.8)$ & \\
\hline M2 & 76 & $13(65)$ & $63(30)$ & \\
\hline M3 & 36 & $5(25)$ & $31(15)$ & \\
\hline M4 & 34 & $0(0)$ & $34(16)$ & \\
\hline M5 & 21 & $0(0)$ & $21(10)$ & \\
\hline M6 & 8 & $0(0)$ & $8(3.8)$ & \\
\hline \multirow[t]{2}{*}{ M7 } & 1 & $0(0)$ & $1(0.5)$ & \\
\hline & & Patients (\%) & Patients (\%) & \\
\hline \multicolumn{5}{|l|}{ Cytogenetics } \\
\hline \multicolumn{5}{|l|}{ Abnormal } \\
\hline$t(15 ; 17)$ & 36 & $5(25)$ & $31(15)$ & .184 \\
\hline $\mathrm{t}(8 ; 21)$ & 20 & $0(0)$ & $20(10)$ & .149 \\
\hline $\operatorname{inv}(16)$ & 3 & $0(0)$ & $3(1)$ & .760 \\
\hline trisomy 8 & 4 & $1(5)$ & $3(1)$ & .307 \\
\hline Other trisomies & 7 & $0(0)$ & $7(3)$ & .524 \\
\hline All others including monosomies, deletions or combination of these & 22 & $2(10)$ & $20(10)$ & .594 \\
\hline Complex karyotype & 8 & $0(0)$ & $8(4)$ & .477 \\
\hline Normal & 126 & $11(55)$ & $115(55)$ & .587 \\
\hline
\end{tabular}

Abbreviation: IDH $1^{\mathrm{m}}, \mathrm{IDH} 1$ mutated; IDH $1^{\text {wt }}, \mathrm{IDH} 1$ wild type

* Fisher exact test unless otherwise indicated; ${ }^{\dagger}$, the student $t$ - test

promotes oncogenesis in both glioma and AML $[9,11,20,33]$. In the p.I99M case, isoleucine was substituted by methionine which was recently identified as a novel missense mutation in the Chinese cohort by Zou et al [28]. The same study revealed that this evolutionary point mutation was also located in the substrate binding site of enzyme and may drive pathogenesis; however, the exact mechanism needs further investigation. In addition, we detected one silent polymorphism $\left(I D H 1^{\mathrm{G} 105 \mathrm{G}}\right)$ in 3 cases $(1.3 \%)$. Wagner et al. [21] previously reported that $I D H 1^{\mathrm{G} 105 \mathrm{G}}$ allele conferred an adverse prognostic impact to patients' survival.

The identified $I D H 2$ mutations involved two different types of amino acid substitution spanning exon 4 of the $I D H 2$ gene at arginine 140 and arginine 172 . Of note, the former arginine was replaced by glutamine (R140Q; $\mathrm{n}=20,83.3 \%)$ and the latter arginine was replaced by lysine (R172K; $\mathrm{n}=4,16.7 \%)$. Our study was similar to previous studies which revealed that more than $80 \%$ of the IDH2 mutations involved R140 [15]. R172 mutations were profoundly associated with biological insights and clinical outcome $[15,20]$ while $\mathrm{R} 140$ has not been addressed to associate with any prognostic significance in AML [23]. Therefore, functional validation should be employed to define whether R140 plays a significant role in AML pathogenesis or is simply a genuine polymorphism.

IDH1 mutation was previously reported to be strongly associated with normal karyotype or intermediate risk karyotype AML $[5,15,25,41]$. Noticeably, our present 
Table 3 Characteristics of AML patients with a wild type or mutated IDH2

\begin{tabular}{|c|c|c|c|c|}
\hline Variable & All cases & $I D H 2^{m}$ & $\mathrm{IDH} 2^{\mathrm{wt}}$ & $P^{*}$ \\
\hline No.of cases & 230 & 24 & 206 & \\
\hline No.of males/females & $101 / 129$ & $11 / 13$ & $90 / 116$ & .504 \\
\hline Age, years & & & & $.001^{+}$ \\
\hline Median (range) & $44(13-86)$ & $49.5(38-80)$ & $43(13-86)$ & \\
\hline Hemoglobin, $\mathrm{g} / \mathrm{dL}$ & & & & $.059^{+}$ \\
\hline Median (range) & $7.8(1.4-14.5)$ & $9.25(4.7-12.6)$ & $7.7(1.4-14.5)$ & \\
\hline WBC count, $\times 10^{9} / \mathrm{L}$ & & & & $.789^{\dagger}$ \\
\hline Median (range) & $27.7(0.6-494.4)$ & $29.73(0.89-222)$ & $26.4(0.6-494.4)$ & \\
\hline Platelet, $\times 10^{9} / \mathrm{L}$ & & & & $.048^{+}$ \\
\hline Median (range) & $46(1.8-965)$ & $59(11-965)$ & $45(1.8-852)$ & \\
\hline Percentage of blasts & & & & $.133^{\dagger}$ \\
\hline \multirow[t]{2}{*}{ Median (range) } & $70.19(6.69-95.44)$ & 61.79 (32.52-95.03) & $71.66(6.69-95.44)$ & \\
\hline & & Patients (\%) & Patients (\%) & \\
\hline \multicolumn{5}{|l|}{ FAB classification } \\
\hline MO & 3 & $0(0)$ & $3(1.5)$ & \\
\hline M1 & 51 & $1(4)$ & $50(24)$ & \\
\hline M2 & 76 & $11(46)$ & $65(31)$ & \\
\hline M3 & 36 & $6(25)$ & $30(15)$ & \\
\hline M4 & 34 & $6(25)$ & $28(14)$ & \\
\hline M5 & 21 & $0(0)$ & $20(10)$ & \\
\hline M6 & 8 & $0(0)$ & $8(4)$ & \\
\hline \multirow[t]{2}{*}{ M7 } & 1 & $0(0)$ & $1(0.5)$ & \\
\hline & & Patients (\%) & Patients (\%) & \\
\hline \multicolumn{5}{|l|}{ Cytogenetics } \\
\hline \multicolumn{5}{|l|}{ Abnormal } \\
\hline$t(15 ; 17)$ & 36 & $6(25)$ & $30(14.6)$ & .150 \\
\hline$t(8 ; 21)$ & 20 & $1(4.2)$ & $19(9.2)$ & .355 \\
\hline $\operatorname{inv}(16)$ & 3 & $0(0)$ & $3(1.5)$ & .717 \\
\hline trisomy 8 & 4 & $1(4.2)$ & $3(1.5)$ & .358 \\
\hline Other trisomies & 7 & $2^{\ddagger}(8.2)$ & $5(2.4)$ & .158 \\
\hline All others including monosomies, deletions or combination of these & 22 & $1(4.2)$ & $21(10.2)$ & .301 \\
\hline Complex karyotype & 8 & $0(0)$ & $8(3.8)$ & .408 \\
\hline Normal & 126 & $12(50)$ & $114(55.3)$ & .388 \\
\hline
\end{tabular}

Abbreviation: IDH2 ${ }^{\mathrm{m}}$, IDH2 mutated; IDH2 ${ }^{\text {wt }}$, IDH2 wild type

${ }^{*}$ Fisher exact test unless otherwise indicated; ${ }^{\dagger}$, Student t- test; ${ }^{\ddagger}, 2$ cases of trisomy11 harboring IDH2 R172K mutation

study found that although IDH1 mutation predominantly had normal karyotype $(\mathrm{n}=11 / 20)$, various aberrant karyotype were also found $(\mathrm{n}=8 / 20)$ including 5 cases of $\mathrm{t}(15 ; 17)$. Similarly, although half of $I D H 2-$ mutated cases had normal karyotype $(n=12 / 24), 6$ cases had $\mathrm{t}(15 ; 17)$. Our study showed a higher frequency of $I D H$ mutations in APL with $\mathrm{t}(15 ; 17)(\mathrm{n}=11 / 36$ cases, $31 \%)$ than most other APL series reported $[5,18,24$, 27,29,32] (Table 6). The prognostic significance of $I D H$ mutations in APL patients needs further studies.

To explore if other genetic mutations coexist in AML cases with $I D H$ mutations, we performed mutation analysis of various different genes, i.e. FLT3, NPM1, NRAS and $A M L 1$. IDH1 mutations were found to be most frequently accompanied by NPM1 mutations $(74 \%$ of the cases; $P<0.001)$. Previous studies also demonstrated that IDH1 mutation was significantly associated with NPM1 mutation, ranging from $12.5 \%$ to $67 \%$ as compared to the wild-type IDH1 cases $[5,18,24,25,27,41]$. Similarly, $I D H 2$ mutations were significantly associated with NPM1 mutations (60\% of the cases; $P<0.001$ ) which were comparable to other reports [24-26]. No significant association was found with other molecular alterations including FLT3-ITD, FLT3-TKD, NRAS and $A M L 1$ although FLT3-ITD was also frequently found co-existing with IDH1 mutation in some studies [15,25]. Meanwhile, other authors also showed no significant correlation between either IDH1 or IDH2 mutation and FLT3-TKD, NRAS and AML1 mutation [5,18,24, $27,30,41]$. 
Table 4 Comparison of additional gene mutations in AML patients with and without IDH1 and IDH2 mutations

\begin{tabular}{|c|c|c|c|c|c|c|c|c|c|c|}
\hline $\begin{array}{l}\text { Additional gene } \\
\text { mutations }\end{array}$ & $\begin{array}{c}I D H 1^{m} \\
\mathrm{n}=20 \text { No. }\end{array}$ & $(\%)$ & $I D H 1^{w t} \mathrm{n}=210$ No. & $\%$ & $P^{*}$ & $I D H 2^{m} \mathrm{n}=24$ No. & $\%$ & $I D H 2^{w t} \mathrm{n}=206$ No. & $\%$ & $P^{*}$ \\
\hline NPM1 & & & & & $<.001$ & & & & & $<.001$ \\
\hline Wild type & 5 & $26 \%$ & 140 & $76 \%$ & & 8 & $40 \%$ & 137 & $75 \%$ & \\
\hline Mutated & 14 & $74 \%$ & 45 & $24 \%$ & & 12 & $60 \%$ & 47 & $25 \%$ & \\
\hline FLT3-ITD & & & & & .34 & & & & & .63 \\
\hline Absent & 14 & $82 \%$ & 108 & $74 \%$ & & 13 & $76 \%$ & 109 & $75 \%$ & \\
\hline Present & 3 & $18 \%$ & 38 & $16 \%$ & & 4 & $24 \%$ & 37 & $25 \%$ & \\
\hline FLT3-TKD & & & & & .59 & & & & & .59 \\
\hline Absent & 15 & $94 \%$ & 133 & $91 \%$ & & 15 & $94 \%$ & 133 & $91 \%$ & \\
\hline Present & 1 & $6 \%$ & 33 & $9 \%$ & & 1 & $6 \%$ & 33 & $9 \%$ & \\
\hline$A M L 1$ & & & & & .09 & & & & & .09 \\
\hline Wild type & 15 & $100 \%$ & 147 & $86 \%$ & & 17 & $100 \%$ & 145 & $86 \%$ & \\
\hline Mutated & 0 & $0 \%$ & 23 & $14 \%$ & & 0 & $0 \%$ & 23 & $4 \%$ & \\
\hline NRAS & & & & & .49 & & & & & .42 \\
\hline Wild type & 8 & $89 \%$ & 79 & $81 \%$ & & 9 & $90 \%$ & 78 & $81 \%$ & \\
\hline Mutated & 1 & $11 \%$ & 18 & $19 \%$ & & 1 & $10 \%$ & 18 & $19 \%$ & \\
\hline PML-RARA & & & & & .43 & & & & & .56 \\
\hline Wild type & 3 & $38 \%$ & 12 & $28 \%$ & & 2 & $25 \%$ & 13 & $30 \%$ & \\
\hline Mutated & 5 & $62 \%$ & 31 & $72 \%$ & & 6 & $75 \%$ & 30 & $70 \%$ & \\
\hline
\end{tabular}

With respect to clinical and hematologic parameters, IDH1 mutated cases were frequently females rather than males (15 cases vs. 5 cases) which was similar to the German study by Schnittger et al. [27]. Interestingly, we observed that both $I D H 1$ and $I D H 2$ mutations were predominantly found in AML with maturation (AML-M2; $\mathrm{n}=24 / 44)$ and acute promyelocytic leukemia (APL) (AML-M3; $\mathrm{n}=11 / 44$ ) which were different from AMLM1 as reported by others $[5,27,30]$. Interestingly, the frequency of $I D H 2$ mutation coexisting in AML-M4 of $25 \%$ in our study was comparable with $27 \%$ in the finding reported by Thol et al. [23]. IDH1 or IDH2 mutations did not significantly impact survivals when the whole AML cohort or AML with normal karyotype analyzed ( $P=0.200$ and 0.272 ). We therefore further analyzed OS according to age and NPM1 status. Unfortunately, we could not find a significant difference between IDH1- and IDH2-mutated and wild-type cases $(P=0.471$ and .812$)$ either in the younger age group $(<$ 60 years) or the NPM1-mutated genotype. Our study was consistent with some studies that revealed no impact of $I D H$ mutations on the OS of AML cases although other studies suggested that IDH1 or $I D H 2$ mutations conferred an adverse effect among AML with normal karyotype or AML with favorable genotype (NPM1 mutated/FLT3 wild type) $[15,25-27,41]$. IDH1

Table 5 Incidence of IDH mutations in AML patients from various countries

\begin{tabular}{|c|c|c|c|c|}
\hline Country & No. IDH1m/all cases (\%) & No. of IDH1m/CN-AML (\%) & No. IDH2m/all cases (\%) & No. of IDH2m/CN-AML (\%) \\
\hline \multicolumn{5}{|l|}{$\overline{A S I A}$} \\
\hline \multicolumn{5}{|l|}{ Taiwan } \\
\hline Chou W et al.(2010) [18] & 27/493 (5.5) & $20 / 227(8.8)$ & ND & ND \\
\hline \multicolumn{5}{|l|}{ China } \\
\hline Zou Y et al.(2010) [28] & 4/68 (5.9) & ND & $4 / 48(8.3)$ & ND \\
\hline Zhang Y et al.(2011) [32] & $23 / 365(6.3)$ & $6 / 111(5.4)$ & ND & ND \\
\hline Lin J et al.(2011) [31] & $4 / 110(3.6)$ & ND & ND & ND \\
\hline \multicolumn{5}{|l|}{ Thailand } \\
\hline This study & 20/230 (8.7) & $11 / 126(8.7)$ & $24 / 230(10.4)$ & $12 / 126(9.5)$ \\
\hline EUROPE $^{\ddagger}[21,23-27,30,41]$ & $6.0-10.9$ & $9.4-16.0$ & $2.0^{*}-10.9$ & $3.2^{*}-15.2$ \\
\hline NORTH AMERICA & $2.2-13.7$ & $4.9-16.0$ & $1.3^{*}-19.2$ & $2.4^{*}-19.2$ \\
\hline$[5,15,19,20,22,29]$ & & & & \\
\hline
\end{tabular}

*The authors only identified IDH2 R172K but did not include IDH2 R140Q mutation; ${ }^{\dagger}$ Pediatric acute myeloid leukemia; ${ }^{\ddagger}$ All studies reported during $2010-2011 ;{ }^{f}$ All studies reported during 2009-2011; ND, not determined 
Table 6 Reported frequencies of IDH1 and IDH2 mutations in APL patients worldwide

\begin{tabular}{|c|c|c|c|c|}
\hline Country & No. IDH1m/all cases (\%) & No. of IDH1m in APL (\%) & No. IDH2m/all cases (\%) & No. of $I D H 2 m$ in APL (\%) \\
\hline \multicolumn{5}{|l|}{ ASIA } \\
\hline \multicolumn{5}{|l|}{ Taiwan } \\
\hline Chou W et al.[18] & 27/493 (5.5) & 0/37 (0) & ND & ND \\
\hline \multicolumn{5}{|l|}{ China } \\
\hline Zhang Y et al.[28] & 23/365 (6.3) & 3/77 (3.9) & ND & ND \\
\hline \multicolumn{5}{|l|}{ Thailand } \\
\hline This study & 20/230 (8.7) & 5/36(13.9) & $24 / 230(10.4)$ & $6 / 36(16.7)$ \\
\hline \multicolumn{5}{|l|}{ EUROPE } \\
\hline \multicolumn{5}{|l|}{ Germany } \\
\hline Schnittger S et al.[27] & $93 / 1414(6.6)$ & $2 / 88(2.3)$ & ND & ND \\
\hline \multicolumn{5}{|l|}{ The Netherlands } \\
\hline Abbas S et al.[24] & $55 / 893(6.2)$ & $0 / 21(0)$ & 97/893 (10.9) & $0 / 21(0)$ \\
\hline \multicolumn{5}{|l|}{ NORTH AMERICA } \\
\hline \multicolumn{5}{|l|}{ United States } \\
\hline Mardis E et al.[5] & 16/188 (8.5) & 0/16 (0) & ND & ND \\
\hline Andersson A et al.[29] & $5 / 227(2.2)$ & $0 / 7(0)$ & $3 / 227(1.3)$ & $0 / 7(0)$ \\
\hline
\end{tabular}

ND, not determined

mutation conferred a shorter disease-free survival and IDH2 R172 mutation contributed to a lower complete remission or a higher relapse risk compared to wild-type IDH patients $[25,41]$. Our study may be limited by a small number of cases with $I D H$ alterations and a substantial recruitment of cases with aberrant karyotype [18,23].

The possible oncogenic role of $I D H$ mutations that contribute to AML development has been postulated by available evidence $[20,33,34]$. By structural and functional analysis, $I D H 1$ and $I D H 2$ mutated cells gained the neomorphic enzymatic activity creating a condition with 2HG oncometabolite accumulation which promotes tumorigenesis through inhibiting a cancer-associated transcription factor such as hypoxia-induced factor (HIF) $[19,20,34]$. Moreover, inhibition of normal myeloid differentiation and induction of global DNA hypermethylation by mutated $I D H$ potentially lead to leukemogenesis [33], suggesting that IDH genes and their altered enzymatic pathways may be a potential new target for future drug development for $\mathrm{AML}$ patients. Intriguingly, $I D H 1$ and $I D H 2$ mutations were also found in other myeloid disorders such as myeloproliferative neoplasms (MPN) and myelodysplastic syndrome (MDS) which have a propensity to AML development, although at a much lower frequency than AML $[42,43]$. It was thus speculated that IDH mutations were likely to be associated with disease transformation or progression rather than disease initiation [44-46].

In conclusion, IDH1 and IDH2 mutations occur in a minor subset of newly diagnosed AML patients with a strong association with normal karyotype, AML-M2 subtype, and NPM1 mutation. No significant correlation with other mutations such as FLT3, RAS, and AML1 could be demonstrated. Larger studies are needed to confirm the prognostic impact of IDH1 and IDH2 mutations in AML patients from various ethnic backgrounds. Our results, nevertheless, provide a relevant rationale to utilize these genomic alterations to better characterize AML patients in the future.

\section{Acknowledgements}

The authors wish to thank the staff of the Division of Hematology, Department of Medicine, Faculty of Medicine Siriraj Hospital for the excellent care of the patients in this study. CUA is currently supported by Siriraj Chalermprakiate Fund, Faculty of Medicine Siriraj Hospital, Mahidol University.

\section{Author details}

${ }^{1}$ Department of Immunology, Mahidol University, Bangkok, Thailand. 2Department of Research and Development, Mahidol University, Bangkok, Thailand. ${ }^{3}$ Department of Medicine, Faculty of Medicine Siriraj Hospital, Mahidol University, Bangkok, Thailand. ${ }^{4}$ Division of Hematology, Department of Medicine, Faculty of Medicine Siriraj Hospital, Mahidol University, 2 Prannok Road, Bangkoknoi, Bangkok 10700, Thailand.

\section{Authors' contributions}

SC performed the experiments and data analysis and contributed to the drafting of the manuscript. WT supervised the molecular and data analysis and contributed to the revision of the manuscript. OP and CB contributed to PML-RARA and NPM1 mutational analyses. CUA was responsible for the initiation and execution of the entire project and critical revision of the manuscript. All authors read and approved the final manuscript.

\section{Competing interests}

The authors declare that they have no competing interests.

Received: 31 January 2012 Accepted: 7 March 2012

Published: 7 March 2012

\section{References}

1. Estey E, Dohner H: Acute myeloid leukaemia. Lancet 2006, 368:1894-1907. 
2. Mrozek K, Heerema NA, Bloomfield CD: Cytogenetics in acute leukemia. Blood Rev 2004, 18:115-136.

3. Takahashi S: Downstream molecular pathways of FLT3 in the pathogenesis of acute myeloid leukemia: biology and therapeutic implications. J Hematol Oncol 2011, 4:13.

4. Takahashi S: Current findings for recurring mutations in acute myeloid leukemia. J Hematol Oncol 2011, 4:36.

5. Mardis ER, Ding L, Dooling DJ, Larson DE, McLellan MD, Chen K, Koboldt DC, Fulton RS, Delehaunty KD, McGrath SD, et al: Recurring mutations found by sequencing an acute myeloid leukemia genome. $N$ Engl J Med 2009, 361:1058-1066.

6. Briere JJ, Favier J, Gimenez-Roqueplo AP, Rustin P: Tricarboxylic acid cycle dysfunction as a cause of human diseases and tumor formation. Am J Physiol Cell Physiol 2006, 291:C1114-C1120.

7. Seyfried TN, Shelton LM: Cancer as a metabolic disease. Nutr Metab (Lond) 2010, 7:7.

8. Dang L, White DW, Gross S, Bennett BD, Bittinger MA, Driggers EM, Fantin VR, Jang HG, Jin S, Keenan MC, et al: Cancer-associated IDH1 mutations produce 2-hydroxyglutarate. Nature 2009, 462:739-744.

9. Zhao $S$, Lin $Y, X u$ W, Jiang $W$, Zha Z, Wang $P$, Yu W, Li Z, Gong L, Peng $Y$, et al: Glioma-derived mutations in IDH1 dominantly inhibit IDH1 catalytic activity and induce HIF-1alpha. Science 2009, 324:261-265

10. Corpas FJ, Barroso JB, Sandalio LM, Palma JM, Lupianez JA, del Rio LA: Peroxisomal NADP-Dependent Isocitrate Dehydrogenase. Characterization and Activity Regulation during Natural Senescence. Plant Physiol 1999, 121:921-928.

11. Dang L, Jin S, Su SM: IDH mutations in glioma and acute myeloid leukemia. Trends Mol Med 2010, 16:387-397.

12. Parsons DW, Jones $S$, Zhang $X$, Lin JC, Leary RJ, Angenendt $P$, Mankoo $P$, Carter H, Siu IM, Gallia GL, et al: An integrated genomic analysis of human glioblastoma multiforme. Science 2008, 321:1807-1812.

13. Yan H, Parsons DW, Jin G, McLendon R, Rasheed BA, Yuan W, Kos I, BatinicHaberle I, Jones S, Riggins GJ, et al: IDH1 and IDH2 mutations in gliomas. N Engl J Med 2009, 360:765-773.

14. Bleeker FE, Lamba S, Leenstra S, Troost D, Hulsebos T, Vandertop WP, Frattini M, Molinari F, Knowles M, Cerrato A, et al: IDH1 mutations at residue p.R132 (IDH1(R132)) occur frequently in high-grade gliomas but not in other solid tumors. Hum Mutat 2009, 30:7-11.

15. Marcucci G, Maharry K, Wu YZ, Radmacher MD, Mrozek K, Margeson D, Holland KB, Whitman SP, Becker H, Schwind S, et al: IDH1 and IDH2 gene mutations identify novel molecular subsets within de novo cytogenetically normal acute myeloid leukemia: a Cancer and Leukemia Group B study. J Clin Oncol 2010, 28:2348-2355.

16. Pardanani A, Lasho TL, Finke CM, Mai M, McClure RF, Tefferi A: IDH1 and IDH2 mutation analysis in chronic- and blast-phase myeloproliferative neoplasms. Leukemia 2010, 24:1146-1151.

17. Kosmider O, Gelsi-Boyer V, Slama L, Dreyfus F, Beyne-Rauzy O, Quesnel B, Hunault-Berger M, Slama B, Vey N, Lacombe C, et al: Mutations of IDH1 and IDH2 genes in early and accelerated phases of myelodysplastic syndromes and MDS/myeloproliferative neoplasms. Leukemia 2010, 24:1094-1096.

18. Chou WC, Hou HA, Chen CY, Tang JL, Yao M, Tsay W, Ko BS, Wu SJ, Huang SY, Hsu SC, et al: Distinct clinical and biologic characteristics in adult acute myeloid leukemia bearing the isocitrate dehydrogenase 1 mutation. Blood 2010, 115:2749-2754.

19. Gross $S$, Cairns RA, Minden MD, Driggers EM, Bittinger MA, Jang HG, Sasaki M, Jin S, Schenkein DP, Su SM, et al: Cancer-associated metabolite 2-hydroxyglutarate accumulates in acute myelogenous leukemia with isocitrate dehydrogenase 1 and 2 mutations. J Exp Med 2010, 207:339-344

20. Ward PS, Patel J, Wise DR, Abdel-Wahab O, Bennett BD, Coller HA, Cross JR, Fantin VR, Hedvat CV, Perl AE, et al: The common feature of leukemiaassociated IDH1 and IDH2 mutations is a neomorphic enzyme activity converting alpha-ketoglutarate to 2-hydroxyglutarate. Cancer Cell 2010, 17:225-234.

21. Wagner K, Damm F, Gohring G, Gorlich K, Heuser M, Schafer I, Ottmann O, Lubbert M, Heit W, Kanz L, et al: Impact of IDH1 R132 mutations and an IDH1 single nucleotide polymorphism in cytogenetically normal acute myeloid leukemia: SNP rs11554137 is an adverse prognostic factor. $J$ Clin Oncol 2010, 28:2356-2364.
22. Ho PA, Alonzo TA, Kopecky KJ, Miller KL, Kuhn J, Zeng R, Gerbing RB, Raimondi SC, Hirsch BA, Oehler V, et al: Molecular alterations of the IDH1 gene in AML: a Children's Oncology Group and Southwest Oncology Group study. Leukemia 2010, 24:909-913.

23. Thol F, Damm F, Wagner K, Gohring G, Schlegelberger B, Hoelzer D, Lubbert M, Heit W, Kanz L, Schlimok G, et al: Prognostic impact of IDH2 mutations in cytogenetically normal acute myeloid leukemia. Blood 2010, 116:614-616

24. Abbas S, Lugthart S, Kavelaars FG, Schelen A, Koenders JE, Zeilemaker A, van Putten WJ, Rijneveld AW, Lowenberg B, Valk PJ: Acquired mutations in the genes encoding IDH1 and IDH2 both are recurrent aberrations in acute myeloid leukemia: prevalence and prognostic value. Blood 2010, 116:2122-2126.

25. Paschka P, Schlenk RF, Gaidzik VI, Habdank M, Kronke J, Bullinger L, Spath D, Kayser S, Zucknick M, Gotze K, et al: IDH1 and IDH2 mutations are frequent genetic alterations in acute myeloid leukemia and confer adverse prognosis in cytogenetically normal acute myeloid leukemia with NPM1 mutation without FLT3 internal tandem duplication. J Clin Oncol 2010, 28:3636-3643.

26. Green $C L$, Evans CM, Zhao L, Hills RK, Burnett AK, Linch DC, Gale RE: The prognostic significance of IDH2 mutations in AML depends on the location of the mutation. Blood 2011, 118:409-412.

27. Schnittger S, Haferlach C, Ulke M, Alpermann T, Kern W, Haferlach T: IDH1 mutations are detected in $6.6 \%$ of 1414 AML patients and are associated with intermediate risk karyotype and unfavorable prognosis in adults younger than 60 years and unmutated NPM1 status. Blood 2010, 116:5486-5496.

28. Zou Y, Zeng Y, Zhang DF, Zou SH, Cheng YF, Yao YG: IDH1 and IDH2 mutations are frequent in Chinese patients with acute myeloid leukemia but rare in other types of hematological disorders. Biochem Biophys Res Commun 2010, 402:378-383.

29. Andersson AK, Miller DW, Lynch JA, Lemoff AS, Cai Z, Pounds SB, Radtke I, Yan B, Schuetz JD, Rubnitz JE, et al: IDH1 and IDH2 mutations in pediatric acute leukemia. Leukemia 2011, 25:1570-1577.

30. Patel KP, Ravandi F, Ma D, Paladugu A, Barkoh BA, Medeiros LJ, Luthra R: Acute myeloid leukemia with IDH1 or IDH2 mutation: frequency and clinicopathologic features. Am J Clin Pathol 2011, 135:35-45.

31. Lin J, Qian J, Yao DM, Li Y, Yang J, Chen Q, Chai HY, Xiao GF, Xu WR: Rapid and reliable detection of IDH1 R132 mutations in acute myeloid leukemia using high-resolution melting curve analysis. Clin Biochem 2011, 44:779-783.

32. Zhang Y, Wei H, Wang M, Huai L, Mi Y, Zhang Y, Lin DT, Liu B, Li W, Zhou C, et al: Some novel features of IDH1-mutated acute myeloid leukemia revealed in Chinese patients. Leuk Res 2011, 35:1301-1306.

33. Figueroa ME, Abdel-Wahab O, Lu C, Ward PS, Patel J, Shih A, Li Y, Bhagwat N, Vasanthakumar A, Fernandez HF, et al: Leukemic IDH1 and IDH2 mutations result in a hypermethylation phenotype, disrupt TET2 function, and impair hematopoietic differentiation. Cancer Cell 2010 18:553-567.

34. Xu W, Yang H, Liu Y, Yang Y, Wang P, Kim SH, Ito S, Yang C, Xiao MT, Liu $L X$, et al: Oncometabolite 2-hydroxyglutarate is a competitive inhibitor of alpha-ketoglutarate- dependent dioxygenases. Cancer Cell 2011, 19:17-30

35. Auewarakul CU, Sritana N, Limwongse C, Thongnoppakhun W, Yenchitsomanus PT: Mutations of the FLT3 gene in adult acute myeloid leukemia: determination of incidence and identification of a novel mutation in a Thai population. Cancer Genet Cytogenet 2005, 162:127-134

36. Auewarakul CU, Lauhakirti D, Tocharoentanaphol C: Frequency of RAS gene mutation and its cooperative genetic events in Southeast Asian adult acute myeloid leukemia. Eur J Haematol 2006, 77:51-56.

37. Auewarakul CU, Leecharendkeat $\mathrm{A}$, Tocharoentanaphol C, Promsuwicha $\mathrm{O}$ Sritana N, Thongnoppakhun W: AML1 mutation and its coexistence with different transcription factor gene families in de novo acute myeloid leukemia (AML): redundancy or synergism. Haematologica 2007, 92:861-862.

38. Boonthimat C, Thongnoppakhun W, Auewarakul CU: Nucleophosmin mutation in Southeast Asian acute myeloid leukemia: eight novel variants, FLT3 coexistence and prognostic impact of NPM1/FLT3 mutations. Haematologica 2008, 93:1565-1569.

39. Promsuwicha O, Thongnoppakhun W, Wongkhantee S, Tocharoentanaphol C, Auewarakul CU: Molecular characterization of 
PML-RARa fusion gene with acute promyelocytic leukemia (APL) by nested RT-PCR. Thai J Hematol Transf Med 2005, 15:247-257.

40. Kaplan E, Meier P: Nonparametric estimation from incomplete observations. J Am Stat Assoc 1958, 53:457-481.

41. Boissel N, Nibourel O, Renneville A, Gardin C, Reman O, Contentin N, Bordessoule D, Pautas C, de Revel T, Quesnel B, et al: Prognostic impact of isocitrate dehydrogenase enzyme isoforms 1 and 2 mutations in acute myeloid leukemia: a study by the Acute Leukemia French Association group. J Clin Oncol 2010, 28:3717-3723.

42. Mesa RA, Li CY, Ketterling RP, Schroeder GS, Knudson RA, Tefferi A: Leukemic transformation in myelofibrosis with myeloid metaplasia: a single-institution experience with 91 cases. Blood 2005, 105:973-977.

43. Thol F, Weissinger EM, Krauter J, Wagner K, Damm F, Wichmann M, Gohring G, Schumann C, Bug G, Ottmann O, et al: IDH1 mutations in patients with myelodysplastic syndromes are associated with an unfavorable prognosis. Haematologica 2010, 95:1668-1674.

44. Green A, Beer P: Somatic mutations of IDH1 and IDH2 in the leukemic transformation of myeloproliferative neoplasms. N Engl J Med 2010 362:369-370

45. Pardanani A, Patnaik MM, Lasho TL, Mai M, Knudson RA, Finke C, Ketterling RP, McClure RF, Tefferi A: Recurrent IDH mutations in high-risk myelodysplastic syndrome or acute myeloid leukemia with isolated del (5q). Leukemia 2010, 24:1370-1372.

46. Tefferi A, Lasho TL, Abdel-Wahab O, Guglielmelli P, Patel J, Caramazza D, Pieri L, Finke CM, Kilpivaara O, Wadleigh $\mathrm{M}$, et al: IDH1 and IDH2 mutation studies in 1473 patients with chronic-, fibrotic- or blast-phase essential thrombocythemia, polycythemia vera or myelofibrosis. Leukemia 2010, 24:1302-1309.

doi:10.1186/1756-8722-5-5

Cite this article as: Chotirat et al:: Molecular alterations of isocitrate dehydrogenase 1 and 2 (IDH1 and IDH2) metabolic genes and additional genetic mutations in newly diagnosed acute myeloid leukemia patients. Journal of Hematology \& Oncology 2012 5:5.

\section{Submit your next manuscript to BioMed Central and take full advantage of:}

- Convenient online submission

- Thorough peer review

- No space constraints or color figure charges

- Immediate publication on acceptance

- Inclusion in PubMed, CAS, Scopus and Google Scholar

- Research which is freely available for redistribution

Submit your manuscript at www.biomedcentral.com/submit
C Biomed Central 